\title{
Fiduciary Responsibility and the Green Energy Act, 2009 (Ontario, Canada)
}

\author{
Stephen R.J. Tsuji
}

\begin{abstract}
Analyses of the Green Energy Act (2009) have stated that the act had numerous shortcomings concerning the environmental impacts of the energy projects initiated within its purview. This account addresses the core points of divergence in the policy's creation that are responsible for the problematic effects. The crux of these problems comes from the ambiguity of the concept of green energy within the act due to its lack of a formal definition. The reasons for this anomaly originate from the Legislative Assembly of Ontario's address on the topic and their decision to let it remain ambiguous. This stance raises questions of whether they are fulfilling their fiduciary duties to an acceptable level. Although these questions of duty and obligation are both delicate and necessary when talking about projects that involve Canada's indigenous peoples, it is not limited to them due to the scope of the effects. Ultimately, although the policy was repealed in January 2019, there are many lessons that can be learned from the missteps of the Act.
\end{abstract}

Keywords: environmental justice, fiduciary responsibility, green energy, Ontario, Canada, indigenous peoples

\section{INTRODUCTION}

$\mathbf{T}$ He Green Energy Act (GEA) is an energy policy produced by the Legislative Assembly of Ontario, Canada. The GEA deals with the moderation and proliferation of green energy within Ontario. The content of this discourse focuses on how green energy is defined within the GEA and why it is defined in such a way. These questions are important to the topic of environmental justice due to the rhetoric that frames green energy as a means of combatting large-scale environmental issues in a number of different areas such as ecology, economics, and equity. ${ }^{1}$ Through this small acknowledgment, these answers can grant further insight into the process of transitioning from ideals to application and the

(C) Stephen R.J. Tsuji 2020; Published by Mary Ann Liebert, Inc. This Open Access article is distributed under the terms of the Creative Commons Attribution Noncommercial License (http://creativecommons.org/licenses/by-nc/4.0/) which permits any noncommercial use, distribution, and reproduction in any medium, provided the original author(s) and the source are cited.

Stephen R.J. Tsuji is a master's candidate at School of Environment, Resources, and Sustainability, University of Waterloo in Waterloo, Canada.

${ }^{1}$ Darren McCauley and Raphael Heffron. "Just Transition: Integrating Climate, Energy and Environmental Justice." Energy Policy 119 (2018): 1-7. sort of complicating factors that would interfere with that process. Moreover, the information gleaned from this study can serve to further aid in the analysis of the GEA as a policy and as a tool for broader sustainability goals.

Analysis begins with the primary material of the GEA. This focus shifts to secondary and periphery materials, such as, the acts and policies that precede it, and the GEA's website. Finally, primary sources in the form of Hansard verbatim transcripts of the parliamentary discussions that address the topic of the GEA when it was known as Bill 150, and the Standing Committee on General Government Hansard verbatim transcripts of the public hearings for Bill 150 will be analyzed. Parliamentary Standing Committees ${ }^{2}$ consist of small working groups of elected Members of Provincial Parliament (MPP) tasked with reviewing a specific issue, such as Bill 150. Standing Committees exist for a limited time and hold public hearings where Ontario citizens can participate $^{3}$ by giving a presentation to the Standing

\footnotetext{
${ }^{2}$ Legislative Assembly of Ontario. Committees. Legislative Assembly of Ontario. <https://www.ola.org/en/legislative-busi ness/committees $>$. (Last accessed on January 1, 2020).

${ }^{3}$ Legislative Assembly of Ontario. Participate in Committees. Legislative Assembly of Ontario. <https://www.ola.org/en/getinvolved/participate-committees $>$. (Last accessed on January 2, 2020).
} 
Committee, if they are chosen after making an initial written submission to the Clerk of the Committee.

To provide a comprehensive analysis of the GEA, a means of measuring and evaluating the act is necessary. Although it is possible to conduct this solely through one's a priori sense of ethics, it bears more weight to have a firm tool for measurement. For this purpose, $f$ duciary duty, or obligation, will be used as a tool for the purpose of evaluating how ethical and legal the GEA is with respect to its content. It is only after this evaluation that this document will provide constructive suggestions on how to improve future policies and similar documents of importance with the intent of avoiding the same missteps of the, now, repealed GEA.

\section{BACKGROUND}

In 2009, the Minister of Energy and Infrastructure, George Smitherman, established the GEA under the liberal Government of Ontario, Canada. ${ }^{4}$ The GEA was an omnibus bill, "A bill consisting of a number of related but separate parts that seeks to amend and/or repeal one or several existing Acts and/or to enact one or several new Acts." ${ }^{\circ}$ It was created with the intent of providing revisions to and superseding 20 pieces of legislation. ${ }^{6}$ Ultimately, the GEA portion of the omnibus bill allowed for the streamlining of the Act in an effort to push for the green energy agenda. ${ }^{7}$ A GEA Steering Committee ${ }^{8}$ was formed from the representatives of the following organizations: Ontario Sustainable Energy Association; Community Power Fund (CP Fund); the Pembina Institute; Environmental Defence; The Suzuki Foundation; Ivey Foundation; the Ontario Federation of Agriculture; and the First Nations Energy Alliance. Although the listed parties were noted to have participated in the Steering Committee of the GEA, the extent of their involvement with the GEA and its formation is not clearly defined. This is especially true for the First Nations Energy Alliance, which is a group composed of 20 indigenous communities; the only explicit piece of information

${ }^{4}$ Legislative Assembly of Ontario. George Smitherman. Legislative Assembly of Ontario. <https://www.ola.org/en/mem bers/all/george-smitherman>. Last accessed on April 26, 2020.

${ }^{5}$ Michel Bédard. Omnibus Bills: Frequently Asked Questions. Library of Parliament. Legal and Legislative Affairs Division, Parliamentary Information and Research Service. 1 October 2012. <https://lop.parl.ca/staticfiles/PublicWebsite/Home/Research Publications/BackgroundPapers/PDF/2012-79-e.pdf $>$. (Last accessed on July 27,2020 ).

${ }^{6}$ Green Energy Act, 2009, S.O. 2009, c. 12, Sched. A. $<$ https://www.ontario.ca/laws/statute/09g12>. (Last accessed on July 27, 2020).

${ }^{7}$ Ontario. Legislative Assembly of Ontario (Hansard). 24 February 2009 (Ms. Laurel C. Broten, Member of Provincial Parliament representing the Liberal Party). First Session, 39th Parliament, No. 113, 5013.

${ }^{8}$ Green Energy Act Alliance. (2008). About Us. <https:// web.archive.org/web/20080716002333>; <http:/www.greenenergy act.ca/Page.asp?PageID=751\&SiteNodeID=203>. (Retrieved for: July 16, 2008 via The Internet Archive, Wayback Machine. $<$ www.greenenergyact.ca/Page.asp?PageID $=751 \&$ SiteNodeID $=$ 203>). (Last accessed on April 26, 2020). is that their legal consultant was Cherie Brant. ${ }^{9}$ The circumstances are similar to the other groups mentioned insofar as the details are sparse.

However, over the decade since its implementation, there were increasing concerns about the GEA. There are numerous reports documenting the economic effects as well as the ecological impacts of the projects covered by the act $^{10}$; these studies validate the premise that the GEA produced projects that were not considered green upon their evaluation. With the groundwork laid, we can turn our attention to the focal point of this article: green energy and how it is defined within the GEA; and whether the Government of Ontario met its fiduciary responsibility to the people of Ontario. It should be noted that within Bill 150, the government's fiduciary responsibility to the Aboriginal people was clearly indicated:

(2) This Act [GEA] shall be interpreted in a manner that is consistent with section 35 of the Constitution Act, 1982 and with the duty to consult aboriginal peoples. (Schedule A, Part I, Subsection 1(2) $)^{5}$

2. This Act shall be administered in a manner that promotes community consultation. (Schedule A, Part I, Subsection 2)

\section{METHODS}

The method for obtaining information on the definition of green energy is as follows: the GEA's definition section will be reviewed; followed by the rest of the document; its predecessors; official communication channels; and the primary sources of Hansard verbatim transcripts for parliamentary debates and Standing Committee hearings will be read in their entirety. All instances of green energy will be noted, then evaluated; relevant pieces of information will be used to construct the case for the discussion. Results will be reviewed and evaluated through the use of fiduciary responsibility to the people of Canada. Finally, synthesis will occur with the results and evaluation to produce suggestions for the creation of future policy documents.

\section{RESULTS}

The GEA does not define green energy in any capacity in the definitions sections of the document: Part 1Interpretation and General Application-Chapter 1Definitions and interpretation-Subsection 1, and Part 3-Energy Data-Chapter 15 Section 1-Definitions. ${ }^{11}$ Instead, definitions for Renewable Energy and its derivatives are found in the aforementioned sections. The remainder of the document is devoid of any semblance of a

\footnotetext{
${ }^{9}$ Independent Electricity System Operator. Indigenous Relations. <http://www.ieso.ca/en/Get-Involved/Indigenous-Relations/ Speakers> (Last accessed on April 26, 2020).

${ }^{10}$ Mark Winfield and Brett Dolter. "Energy, Economic and Environmental Discourses and Their Policy Impact: The Case of Ontario's Green Energy and Green Economy Act." Energy Policy 68 (May 1, 2014): 423-435.

${ }^{11}$ Green Energy Act, 2009, S.O. 2009, c. 12, Sched. A. $<$ https://www.ontario.ca/laws/statute/09g12>. (Last accessed on July 27, 2020).
} 
definition for green energy. Concerning its predecessors, many of the original documents have limited accessibility; any documents that were available were reviewed. For those whose official copies were not available, they were accessed using Internet archives. The 20 acts impacted by the GEA included ${ }^{12}$ : Building Code Act, $1992^{13}$; Clean Water Act, $2006^{14}$; Conservation Authorities $\mathrm{Act}^{15}$; Conservation Land $\mathrm{Act}^{16}$; Co-operative Corporations Act $^{17}$; Electricity Act, 1998 ${ }^{18}$; Energy Conservation Leadership Act, $2006^{19}$; Energy Efficiency $\mathrm{Act}^{20}$; Environmental Bill of Rights, $1993^{21}$; Environmental Protection $\mathrm{Act}^{22}$; Greenbelt Act, $2005^{23}$; Ministry of Energy $\mathrm{Act}^{24}$; Ministry of Natural Resources $\mathrm{Act}^{25}$; Niagara Escarpment Planning and Development $\mathrm{Act}^{26}$; Ontario Energy Board Act, $1998^{27}$; Ontario Water Re-

\footnotetext{
${ }^{12}$ Green Energy Act, 2009, S.O. 2009, c. 12, Sched. A. Acts Affected. <https://www.ola.org/en/legislative-business/bills/parlia ment-39/session-1/bill-150/acts-affected $>$. (Last accessed on November 27, 2019).

${ }^{13}$ Building Code Act, 1992, S.O. 1992, c. 23. <https://www .ontario.ca/laws/statute/92b23>. (Last accessed on November 27, 2019).

${ }^{14}$ Clean Water Act, 2006, S.O. 2006, c. 22. <https://www .ontario.ca/laws/statute/06c22? search=Clean+water+act $>$. (Last accessed on November 27, 2019).

${ }^{15}$ Conservation Authorities Act, R.S.O. 1990, c. C.27. <https:// www.ontario.ca/laws/statute/90c27? search=conservation+author ities+act>. (Last accessed on November 27, 2019).

${ }^{16}$ Conservation Land Act, R.S.O. 1990, c. C.28. <https://www .ontario.ca/laws/statute/90c28? search=conservation+land+act $>$.
} (Last accessed on November 27, 2019).

${ }^{17}$ Co-operative Corporations Act, R.S.O. 1990, c. C.35. <https:// www.ontario.ca/laws/statute/90c35?search=co-operative+corpo rations+act>. (Last accessed on November 27, 2019).

${ }^{18}$ Electricity Act, 1998, S.O. 1998, c. 15, Sched. A. <https:// www.ontario.ca/laws/statute/98e15?search=electricity+act $>$. (Last accessed on November 27, 2019).

${ }^{19}$ Energy Conservation Leadership Act, 2006, S.O. 2006, c. 3 Sched. A. <https://www.ontario.ca/laws/statute/06e03>. (Last accessed on November 27, 2019).

${ }^{20}$ Energy Efficiency Act, R.S.O. 1990, c. E.17. <https://www .ontario.ca/laws/statute/90e17>. (Last accessed on November 27, 2019).

${ }^{21}$ Environmental Bill of Rights, 1993, S.O. 1993, c. $28 .<$ https:// www.ontario.ca/laws/statute/93e28?search=environmental+bill+ of +rights $>$. (Last accessed on November 27, 2019).

${ }^{22}$ Environmental Protection Act, R.S.O. 1990, c. E.19. <https:// www.ontario.ca/laws/statute/90e19? search=environmental+ protection+act>. (Last accessed on November 27, 2019).

${ }^{23}$ Greenbelt Act, 2005, S.O. 2005, c. 1. <https://www.ontario .ca/laws/statute/05g01?search=greenbelt+act $>$. (Last accessed on November 27, 2019)

${ }^{24}$ Ministry of Energy Act, 2011, S.O. 2011, c. 9, Sched. 25. $<$ https://www.ontario.ca/laws/statute/11m09a?search=ministry+ of +energy+act>. (Last accessed on November 27, 2019).

${ }^{25}$ Ministry of Natural Resources Act, R.S.O. 1990, c. M.31 $<$ https://www.ontario.ca/laws/statute/90m31?search=Ministry+ of + Natural+Resources+Act $>$. (Last accessed on November 27, 2019).

${ }^{26}$ Niagara Escarpment Planning and Development Act, R.S.O. 1990, c. N.2. <https://www.ontario.ca/laws/statute/90n02? search= Niagara+escarpment+planning+and+development+act>. (Last accessed on November 27, 2019).

${ }^{27}$ Ontario Energy Board Act, 1998, S.O. 1998, c. 15, Sched. B. <https://www.ontario.ca/laws/statute/98o15?search=ontario+ energy+board+act>. (Last accessed on November 27, 2019). sources $\mathrm{Act}^{28}$; Places to Grow Act, 2005 ${ }^{29}$; Planning $\mathrm{Act}^{30}$; Provincial Parks and Conservation Reserves Act, 2006 ${ }^{31}$; Public Lands $\mathrm{Act}^{32}$; and Renewable Energy Standard Offer Program. ${ }^{33}$ There is no mention of green energy in any of the preceding documents. Conclusively, a definition for the term green energy is absent from all official parliamentary documents.

Although there is no mention of any official definition of green energy within any parliamentary document, there are mentions of it found on the websites associated with the act; however, similar to many of the older documents, there is no longer an official accessible version of these sites. Fortunately, there are archived versions that will be used as evidence for the existence of a definition; although separate from the act's official documents.

The first instance is the GEA's official website, which has been deactivated and serves as a redirect to the Environmental Defence's website. ${ }^{34}$ Using Internet archives, certain portions of the site have been recovered. In the recovered portion of the site, they do not define green energy in their "Green Energy Dictionary.,"35 However, it is described in another section of their site that is specifically dedicated to the topic of green energy; within this section, it is described as "Green energy is an environmentally friendly, sustainable source of electricity. It has several key components. The first is renewable energy-electricity that is generated using easily available, naturally occurring fuel sources such as water flows,

\footnotetext{
${ }^{28}$ Ontario Water Resources Act, R.S.O. 1990, c. O.40. <https:// www.ontario.ca/laws/statute/90o40? search=ontario+water+ resources+act>. (Last accessed on November 27, 2019).

${ }^{29}$ Places to Grow Act, 2005, S.O. 2005, c. 13. <https://www .ontario.ca/laws/statute/05p13? search=places+to+grow+act $>$. (Last accessed on November 27, 2019).

${ }^{30}$ Planning Act, R.S.O. 1990, c. P.13. <https://www.ontario $. c a /$ laws/statute/90p13?search=planning+act $>$. (Last accessed on November 27, 2019).

${ }^{31}$ Provincial Parks and Conservation Reserves Act, 2006, S.O. 2006, c. 12 . <https://www.ontario.ca/laws/statute/06p12?search= provincial+parks+and+conservation+reserves+act>. (Last accessed on November 27, 2019).

${ }^{32}$ Public Lands Act, R.S.O. 1990, c. P.43. <https://www .ontario.ca/laws/statute/90p43 ? search=public+lands+act $>$. (Last accessed on November 27, 2019).

${ }^{33}$ Ontario Energy Board. (2005). Standard Offer Program (EB-2005-0463). <https://web.archive.org/web/20051221172907/>; <http:/www.oeb.gov.on.ca/html/en/industryrelations/ongoingproj ects_standardofferprogram.htm $>$ (Retrieved for: December 1, 2005 via The Internet Archive, Wayback Machine). <http:// www.oeb.gov.on.ca/html/en/industryrelations/ongoingprojects standardofferprogram.htm $>$. (Last accessed on November 27, 2019).

${ }^{34}$ Environmental Defence. Climates \& Clean Economy. (Redirected to $<$ https://environmentaldefence.ca/campaign/climateand-clean-economy $>$. Redirected from <http://www.green energyact.ca $>$ ). (Last accessed on September 18, 2019).

${ }^{35}$ Green Energy Act Alliance. (2008). Green Energy Dictionary. <https://web.archive.org/web/20080716002806>; <http:// www.greenenergyact.ca/Page.asp?PageID $=122 \&$ ContentID $=$ 886>. (Retrieved for: July 16, 2008 via The Internet Archive, Wayback Machine. <http://www.greenenergyact.ca/Page.asp? PageID $=122 \&$ ContentID=886 $>$ ). (Last accessed on April 26, 2020).
} 
energy from the sun, wind energy and waste. The second is conservation - the conscious reduction of electricity consumption - by being smarter about how, where and when we use it. A third aspect of green energy is its ability to effectively generate electricity on a much smaller scale than traditional 'big power' stations that use coal and nuclear fuels. This allows generation to be located much closer to where it is consumed. This form of green energy is called Community Power." 36 This definition is the most explicit definition of green energy found out of the wealth of parliamentary documents related to the GEA and official media on the topic presented through websites.

The first point of primary analysis other than the GEA itself deals with the Hansard transcriptions of the parliamentary debates held within the Legislative Assembly of Ontario. The most explicit comment with respect to green energy is made by the Liberal Party in regard to the purpose of the bill; it was stated: "our duty and obligation is to do something about [climate change]... in order to help the environment and create green energy to serve our needs for industrial and domestic use." ${ }^{37}$ There are other mentions of green energy; however, most of them share the same level of information as what is found on the Green Energy Act Alliance's website in terms of what modes of energy production are included under the title green energy. ${ }^{38}$ Within the debates there were also mentions, from Liberal Party members, which identified green energy and clean energy as two separate types of energy. ${ }^{39}$ In other statements, made by the Liberal Party, there are those that assert that green energy and renewable energy are interchangeable terms, if not completely synonymous. ${ }^{40}$

In the GEA Standing Committee hearings, the public described the impacts of green energy as not being harmful to the health of the environment, animals, and people locally and regionally (Table 1). Peter Tabuns of the New Democratic Party of Ontario, an MPP and the GEA Standing Committee, introduced a GEA amendment that defined green energy; his amendment was soundly defeated with no alternative definitions for green energy being offered by his detractors (Table 1). During GEA Standing Committee hearings, George Smitherman

\footnotetext{
${ }^{36}$ Green Energy Act Alliance. (2008). About Green Energy. <https://web.archive.org/web/20080716002317>; <http://www .greenenergyact.ca/Page.asp?PageID $=1224 \&$ SiteNodeID $=201>$. (Retrieved for: July 16, 2008 via The Internet Archive, Wayback Machine. $<$ http://www.greenenergyact.ca/Page.asp?PageID=1224\& SiteNodeID=201>). (Last accessed on April 26, 2020).

${ }^{37}$ Ontario. Legislative Assembly of Ontario (Hansard). 26 February 2009 (Mr. Khalil Ramal, Member of Provincial Parliament representing the Liberal Party). No. 115, 5074.

${ }^{38}$ Ontario. Legislative Assembly of Ontario (Hansard). 2 April 2009 (Mr. Reza Moridi, Member of Provincial Parliament representing the Liberal Party). First Session, 39th Parliament, No. 120,5338 .

${ }^{39}$ Ontario. Legislative Assembly of Ontario (Hansard). 2 March 2009 (Hon. Dalton McGuinty, Premier of Ontario). First Session, 39th Parliament, No. 116, 5118.

${ }^{40}$ Ontario. Legislative Assembly of Ontario (Hansard). 9 March 2009 (Mr. Mike Colle, Member of Provincial Parliament representing the Liberal Party). First Session, 39th Parliament, No. 120, 5336.
}

states that nuclear power is not covered by the GEA (Table 1). However, other Liberal Party members during Legislative Assembly of Ontario deliberations clearly assert that nuclear energy is part of the GEA and its green energy strategy (Table 1). There were tangible benefits for the Liberal Party by not defining green energy and likewise, clearly describing green energy strategy in the GEA; green energy and green energy strategy could be whatever one believed it to be, even nuclear-power generation with its radioactive waste. ${ }^{41,42}$ Possibilities of mishandling, accident, and disaster only exacerbate the damage to the environment, ecological and social. ${ }^{43,44}$

There is one specific comment that is of importance to how you define green energy, especially with respect to impacts on indigenous peoples: "It comes down to a very minute description of how you would define green energy. I would say that hydro-electric-that's water dams - would be green energy, with the exception that often, to create a dam, you have to flood property. In many cases, it's property that has been affecting First Nations for hundreds of years. It's a huge issue in Quebec [Canada]. They have hydroelectric power, and for most of it they flooded land that was in dispute in the courts." 45 This comment from O'Toole indicates that concerns regarding the definition were explicitly brought to the attention of the Liberal Party before the bill was made into the GEA; these concerns outline previous relevant instances within the Province of Quebec. This is to say that the Liberal Party was given fair warning and critique about the possible negative impacts the bill would have on the environment if left unchecked. This statement not only addresses these concerns, but also identifies a likely contributor to these ill effects; he specifically states that the pivotal point in this discussion is how the Liberal Party would define the term green energy. Despite this warning, green energy went undefined within the GEA and many of the official documents. The only instance where it was defined in any capacity was on the GEA website, as noted previously-

\footnotetext{
${ }^{41}$ U.S. Energy Information Administration: Independent Statistics and Analysis. (2020, January 15). Nuclear Power Explained. <https://www.eia.gov/energyexplained/nuclear/nuclearpower-and-the-environment.php>. (Last accessed on July 27, 2020).

${ }^{42}$ Jordi Bruno and Rodney C. Ewing. "Spent Nuclear Fuel." Elements (Quebec) 2 (Dec 1, 2006): 343-349.

${ }^{43}$ Toshihide Tsuda, Akiko Tokinobu, Eiji Yamamoto, and Etsuji Suzuki. "Thyroid Cancer Detection by Ultrasound Among Residents Ages 18 Years and Younger in Fukushima, Japan: 2011 to 2014." Epidemiology 27 (2016): 316-322.

${ }^{44}$ Larisa N. Astakhova, Lynn R. Anspaugh, Gilbert W. Beebe, André Bouville, Vladimir V. Drozdovitch, Vera Garber, Yuri I. Gavrilin, Valeri T. Khrouch, Arthur V. Kuvshinnikov, Yuri N. Kuzmenkov, Victor P. Minenko, Konstantin V. Moschik, Alexander S. Nalivko, Jacob Robbins, Elena V. Shemiakina, Sergei Shinkarev, Svetlana I. Tochitskaya, Myron A. Waclawiw, and Andre Bouville. "Chernobyl-Related Thyroid Cancer in Children of Belarus: A Case-Control Study." Radiation Research 150 (1998): 349.

${ }^{45}$ Ontario. Legislative Assembly of Ontario (Hansard). 3 March 2009 (Mr. John O'Toole, Member of Provincial Parliament representing the Progressive Conservative Party). First Session, 39th Parliament, No. 117, 5172-5173.
} 
and this definition was tailored in such a way as to seem amicable while doing nothing to represent the truth of the GEA - this is how the state of the definition would remain until its repeal in the January of 2019. With the information gleaned from the investigation of the transcriptions of the debates in the Legislative Assembly of Ontario, and the hearings of the GEA Standing Committee, we can conclude the results portion of the definition section of this document.

The next question that needs to be addressed is: Why was green energy defined in such a way? The parliamentary transcriptions also indicate that there were similar questions asked by both the Progressive Conservative Party ${ }^{46}$ and the New Democratic Party. ${ }^{47}$ Among the statements given, there were two main critical observations that were made with respect to the reason why the GEA lacked an adequate definition. The first observation introduced the possibility that the GEA is only using the term green energy to garner acceptance with the public due to its usage of the term green ener$g y^{48}$; even for those who are not as savvy with the intricacies of the term in the area of energy production, the choice of words has amicable connotations that imply positivity. ${ }^{49}$ Consequently, regardless of the level of knowledge of the public, it is a term that demands attention and support.

Another concern that is mentioned is one that follows from the first due to the favorable dispositions people have with the term green energy for reasons that were outlined previously. The term green energy carries weight due to its relationship with movements toward a sustainable future in the face of the global topic of climate change. Owing to this weight and favorable light, many members of the Progressive Conservative Party identified the difficulty to be had with showing criticism for the bill being passed. ${ }^{50}$ Although criticism was much more difficult than simply denouncing the bill, a great deal of it was still present within the parliamentary discussions and GEA Standing Committee hearings, especially with respect to due process. Members of Parliament commented on the lack of the normal consultative process before a bill is written, as well as the

\footnotetext{
${ }^{46}$ Ontario. Legislative Assembly of Ontario (Hansard). 12 May 2009 (Mr. John O'Toole, Member of Provincial Parliament representing the Progressive Conservative Party). First Session, 39th Parliament, No. 149, 6779.

${ }^{47}$ Ontario. Legislative Assembly of Ontario (Hansard). 26 February 2009 (Mr. Paul Miller, Member of Provincial Parliament representing the New Democrat Party). First Session, 39th Parliament, No. 115, 5070.

${ }^{48}$ Ontario. Legislative Assembly of Ontario (Hansard). 12 May 2009 (Mr. Jim Wilson, Member of Provincial Parliament representing the Progressive Conservative Party). First Session, 39th Parliament, No. 149, 6766.

${ }^{49}$ Ontario. Legislative Assembly of Ontario (Hansard). 3 March 2009 (Mr. John O'Toole, Member of Provincial Parliament representing the Progressive Conservative Party). First Session, 39th Parliament, No. 117, 5172.

${ }^{50}$ Ontario. Legislative Assembly of Ontario (Hansard). 12 May 2009 (Mr. John O’Toole, Member of Provincial Parliament representing the Progressive Conservative Party). First Session, 39th Parliament, No. 149, 6779.
}

termination of the current legislative review process allowing oversight by municipalities and the public (Table 2). Moreover, Brad Duguid, the Minister of Aboriginal Affairs for the Provincial Liberal Government rightfully noted that there is a constitutional obligation of the duty to consult with Aboriginal peoples as a minimum; and, one Member of Parliament commented that the people in Ontario in general were selectively left out of the consultative process (Table 2). Finally, at a GEA Standing Committee hearing, Beatrice Olivastri, CEO of Friends of the Earth's Canada, brought up a point of concern: the Ministry of Energy and Infrastructure was not a prescribed Government of Ontario Ministry to the Environmental Bill of Rights (Table 2). Thus, green energy projects under the GEA would not be bound by "Part II-Public Participation in Government Decision Making" of the Environmental Bill of Rights (Table 2). Overall, the approval process of green energy projects under the GEA in Ontario was streamlined by removing legislative and public oversight.

\section{DISCUSSION}

Summarily, the definition of green energy within the GEA is lacking; although it is defined within the GEA's official site, it is not present in any official documentation used by Ontario's Legislature. However, for the sake of argument, we will consider the definition presented on the, now-defunct, website to be a valid definition put forth by the GEA for supplementary purposes. To evaluate this, Canada has a convenient neighbor they can measure up against; in the United States of America, green energy, or green power, is defined as "Green power is a subset of renewable energy and represents those renewable energy resources and technologies that provide the highest environmental benefit." ${ }^{21}$ This is a concise definition that is coherent with the reasoning for the difference in naming conventions and the close relationship with renewable energy; however, there is no equivalence between the terms. If there was equivalence, it likely would have been stated within the GEA; even outside the act, the website only has a vague definition that is further defined by three components that do little to emphasize the purpose of green energy_ " the highest environmental benefit." 52 With this, it is shown that the definition is absent from the GEA, and the source that does state the definition is worded in such a loose manner that it serves only a fraction of the purpose in comparison with others who have defined it.

Given the warnings of the other parties within Ontario's Parliament, it can also be inferred that the ambiguity of the definition was intentional, for one reason or another. The fact of the matter is that suggestions and critiques were ignored by the governing Liberal Party of Ontario. The fact that these suggestions were ignored is

\footnotetext{
${ }^{51}$ United States Environmental Protection Agency. What Is Green Power? <https://www.epa.gov/greenpower/what-greenpower>. (Last accessed on April 26, 2020).$$
{ }^{52} \text { Ibid. }
$$ 
evident of a greater concern that involves the Government of Ontario's fiduciary duty to its peoples.

Fiduciary duty exists as both a concept in ethics and as a legal concept that is especially applicable to indigenous peoples under 35 of the Constitution Act of 1982; in short, "one party has an obligation to act for the benefit of another" in instances where the former party is entrusted with power over the latter to make decisions in their best interest. ${ }^{53}$ There are those that may remain unconvinced of the need for judicial involvement on the matter; however, Dianne Saxe, who represents "the 18,000 lawyers of the Ontario Bar Association" 54 at the time stated that "[the GEA does not] deal with aboriginal rights in a coherent way." ${ }^{, 5}$ This is indicative of problems at a legal level from experts on the topic.

One of the possible avenues that provide difficulty is the "duty to consult" 56 ; and the Constitutional obligation of duty to consult was explicitly mentioned in the GEA, and by Brad Duguid, Minister of Aboriginal Affairs, with the added caveat of going beyond that obligation (Table 3). Although an indigenous group was represented in the steering committee, it is still unknown what role the committee played in the GEA, if at all; nor is it known about the inclusivity of the group. However, indigenous representation during the GEA Standing Committee hearings can be evaluated, because we have access to the Hansard verbatim-transcripts.

Although there was First Nation representation at the GEA Standing Committee hearings, none of the 10 representatives were elected or traditionally recognized First Nation representatives, and only one was a designate of an elected chief. Thus, not one elected or traditionally recognized First Nation Chief or Councilor was part of the GEA Standing Committee hearings (Table 4). The issue is that only elected or traditional leadership, such as Chiefs and Councils, which are informed by their communities can make decisions with respect to Aboriginal and/or treaty rights (Table 3). First Nation leadership did not attend the GEA Standing Committee hearings; however, leadership did attend Standing Committee hearings for Bill 173 (Mining Act Amendment) and Bill 191 (Far North Act) that were held during 2009, the same year as the GEA Standing Committee hearings. From the Hansard transcripts, although directly related to Bills 173 and 191, it is still possible to gain some understanding of First Nations' leadership with respect to Aboriginal and

\footnotetext{
${ }^{53}$ Supreme Court of Canada. Guerin v The Queen. <https:// scc-csc.lexum.com/scc-csc/scc-csc/en/item/2495/index.do, 336>. (Last accessed on April 26, 2020).

${ }^{54}$ Ontario. Standing Committee on General Government (Hansard). 20 April 2009 (Ms. Dianne Saxe, Representing the Ontario Bar Association). First Session, 39th Parliament, G25, 621.

${ }^{55}$ Ontario. Standing Committee on General Government (Hansard). 20 April 2009 (Ms. Dianne Saxe, Representing the Ontario Bar Association). First Session, 39th Parliament, G25, 622.

${ }^{56}$ Government of Canada. Indigenous and Northern Affairs Canada. <https://www.aadnc-aandc.gc.ca/eng/1331832510888/ 1331832636303>. (Last accessed on Apr 26, 2020).
}

treaty rights; consultation with the Government of Ontario; and development in general, especially hydroelectric power generation.

In brief, from a First Nations' perspective, consultation must be at the community level with the people who hold Aboriginal and/or treaty rights, and with the First Nation leadership who can make decisions on issues that impacts Aboriginal and/or treaty rights (Table 3). Of particular importance, with respect to the GEA, are the cautionary tales about the devastating impacts of development; this is especially true of the hydroelectric power generation development on First Nations' homelands in Ontario (Table 3). Given these statements, one should question why elected and traditional leadership were absent from the GEA Standing Committee hearings. A possibility that should be considered is in the naming convention of the GEA with respect to the concept of green energy. The argument that is presented extends beyond the scope of this article, but it is something that should be considered.

Finally, there were many shortcomings with the GEA that involved numerous complaints from various groups of people. Even if the GEA forcefully passed the legal requisites for Fiduciary Duty, it is evident that they did not perform their ethical, yet informal, duty to remaining stakeholders in this dialogue. As with research involving people; it is the duty of the initiating party to ensure that information is communicated clearly in a way that is understandable to the other parties. It cannot be conclusively said whether this was the root of the problem or not; regardless of that fact, it stands as another pivotal point for improvement.

Before the closing, it should also be acknowledged that these topics and discussions also fall under the domain of energy justice, a subsection of environmental justice that deals with the ethical considerations with respect to energy. Much of the topic of energy justice deals with the production and distribution aspects of energy and topics of equity, equality, ethics, and fairness $^{37}$; intuitively, the NIMBYism aspect of this discussion falls under this category due to the indigenous communities and consultations factors. ${ }^{58}$ However, an argument can also be made for the critique of the policy itself, and its misleading rhetoric that was used to elicit a specific response to the GEA. Although these are all topics that are deserving of attention, they are all complex issues that have strong prescriptive components due to the ethical nature of these topics ${ }^{59}$; they require much more depth than what can be given in this

\footnotetext{
${ }^{57}$ Caroline Damgaard, Darren McCauley, and Jed Long. "Assessing the Energy Justice Implications of Bioenergy Development in Nepal." Energy, Sustainability and Society 7 (Dec 2017): 1-16.

${ }^{58}$ Dayna Nadine Scott and Adrian A. Smith. "Sacrifice Zones" in the Green Energy Economy: Toward an Environmental Justice Framework." McGill Law Journal 62 (2017): $861-898$.

${ }^{59}$ Benjamin K. Sovacool and Michael H. Dworkin. "Energy Justice: Conceptual Insights and Practical Applications." Applied Energy 142 (Mar 2015): 435-444.
} 
Table 1. Defining Green Energy and Green Energy Strategy from the Green Energy (Bill 150) Standing Committee Hearings

\begin{tabular}{|c|c|}
\hline Speaker/citation & Comments \\
\hline \multicolumn{2}{|l|}{ General public } \\
\hline $\begin{array}{l}\text { Barry Fraser of Fraser } \\
\text { Consulting and Associates }\end{array}$ & $\begin{array}{l}\text { "Green energy must not compromise the health and safety of our } \\
\text { environment but, rather, enhance it... green energy development must } \\
\text { not compromise the health and safety of [animals]... as well as people } \\
\text { in both rural and urban Ontario.". }\end{array}$ \\
\hline $\begin{array}{l}\text { Harvey Tenenbaum } \\
\text { of Harten Consulting }\end{array}$ & $\begin{array}{l}\text { "If Bill } 150 \text { is to provide the impetus for green energy and, just as } \\
\text { importantly, a green environment-and that's the purpose for green } \\
\text { energy, to ensure a green environment." }\end{array}$ \\
\hline $\begin{array}{l}\text { Lou Eyamie of Save } \\
\text { Our Skyline G24, p } 570^{62}\end{array}$ & $\begin{array}{l}\text { On green energy projects "do not harm the environment, do not increase } \\
\text { risk to threatened species and pose no risk or health threat to the } \\
\text { people and animals that live near proposed sites." }\end{array}$ \\
\hline \multicolumn{2}{|l|}{ Members of Provincial Parliament } \\
\hline $\begin{array}{l}\text { Peter Tabuns [New } \\
{\text { Democratic Party }]^{63}}^{63}\end{array}$ & $\begin{array}{l}\text { "I move that subsection 1(1) of the Green Energy Act, } 2009 \text {, as set out } \\
\text { in schedule A to the bill, be amended by adding the following } \\
\text { definitions: 'green energy' means energy derived from a renew-able } \\
\text { energy source or from a generation facility that is a high-efficiency } \\
\text { heat and power facility; "high-efficiency heat and power facility' } \\
\text { means a generation facility that uses high-efficiency technology to } \\
\text { produce power and thermal energy from a single source and that } \\
\text { achieves a minimum average efficiency of } 6,000 \text { British thermal units } \\
\text { per kilowatt hour but does not include a generation facility that uses } \\
\text { garbage or refuse-derived fuel." }\end{array}$ \\
\hline Laurel C. Broten [Liberal Party] ${ }^{64}$ & $\begin{array}{l}\text { "We will not be accepting this amendment. The focus of the Green } \\
\text { Energy Act is with respect to renewable energy generation.", }\end{array}$ \\
\hline Mr. David Orazietti (The Chair) & "The amendment is lost." \\
\hline [Liberal Party] ${ }^{65}:$ & $\begin{array}{l}\text { Ayes }=\text { "Tabuns" } \\
\text { Nays }=\text { "Bailey, Broten, Jeffrey, Kular, Mitchell, Rinaldi, Yakabuski." }\end{array}$ \\
\hline $\begin{array}{l}\text { George Smitherman } \\
\text { (Minister of Energy } \\
\text { and Infrastructure) } \\
\text { [Liberal Party] }^{66}\end{array}$ & $\begin{array}{l}\text { "Nuclear power is not covered by the Green Energy Act... we haven't } \\
\text { sought to have the Green Energy Act apply to nuclear power, no." }\end{array}$ \\
\hline Laurel C. Broten [Liberal Party] ${ }^{67}$ & $\begin{array}{l}\text { "It [nuclear power] is part of a green energy strategy [for the Green } \\
\text { Energy Act, 2009] going forward., } 2\end{array}$ \\
\hline Carol Mitchell [Liberal Party] ${ }^{68}$ & $\begin{array}{l}\text { "I' } m \text { very proud of the Green Energy Act. I'm very proud that nuclear is } \\
\text { an important component of it...I have the largest nuclear generating } \\
\text { station in North America located in my riding.", }\end{array}$ \\
\hline
\end{tabular}

\footnotetext{
${ }^{60}$ Ontario. Standing Committee on General Government (Hansard). 15 April 2009 (Mr. Barry Fraser, representing Fraser Consulting and Associates). First Session, 39th Parliament, G23, $529-530$.

${ }^{61}$ Ontario. Standing Committee on General Government (Hansard). 20 April 2009 (Mr. Harvey Tenenbaum, representing Harten Consulting). First Session, 39th Parliament, G25, 643.

${ }^{62}$ Ontario. Standing Committee on General Government (Hansard). 16 April 2009 (Mr. Lou Eyamie, representing Save Our Skyline). First Session, 39th Parliament, G24, 570.

${ }^{63}$ Ontario. Standing Committee on General Government (Hansard). 27 April 2009 (Mr. Peter Tabuns, Member of Provincial Parliament representing the New Democrat Party). First Session, 39th Parliament, G27, 687.

${ }^{64}$ Ontario. Standing Committee on General Government (Hansard). 27 April 2009 (Ms. Laurel C. Broten, Member of Provincial Parliament representing the Liberal Party). First Session, 39th Parliament, G27, 687.
}

\footnotetext{
${ }^{65}$ Ontario. Standing Committee on General Government (Hansard). 27 April 2009 (Mr. David Orazietti, The Chair). First Session, 39th Parliament, G27, 687-688.

${ }^{66}$ Ontario. Standing Committee on General Government (Hansard). 8 April 2009 (Hon. George Smitherman, Minister of Energy and Infrastructure). First Session, 39th Parliament, G21, 414.

${ }^{67}$ Ontario. Legislative Assembly of Ontario (Hansard). 26 February 2009 (Ms. Laurel C. Broten, Member of Provincial Parliament representing the Liberal Party). First Session, 39th Parliament, No. 115, 5072.

${ }^{68}$ Ontario. Legislative Assembly of Ontario (Hansard). 11 May 2009 (Mrs. Carol Mitchell, Member of Provincial Parliament representing the Liberal Party). First Session, 39th Parliament, No. 148, 6725.
} 
Table 2. Due Process Concerns as Informed by Legislative Assembly of Ontario Deliberations and Green Energy ACt Standing Committee hearings on Bill 150

(GreEn ENERGy AND GREen ECONOMY ACT, 2009)

\begin{tabular}{|c|c|}
\hline Speaker/citation & Comments \\
\hline \multicolumn{2}{|c|}{ Legislative Assembly of Ontario Deliberations } \\
\hline Ted Arnott [Progressive & "The first question that \\
\hline $\begin{array}{l}\text { Conservative Party] No. } \\
114, \text { p } 5047^{69}\end{array}$ & $\begin{array}{l}\text { parliamentary tradition of introducing a bill, then allowing the opposition a few days, at least, to } \\
\text { consult with interested stakeholders and the public? [emphasis added] What details are buried in this } \\
\text { bill that the government doesn't want people to know about? What are they trying to hide?" }\end{array}$ \\
\hline $\begin{array}{l}\text { Peter Shurman } \\
\quad \text { Progressive }\end{array}$ & $\begin{array}{l}\text { "We also know that the reason that this bill has been introduced now, without proper briefings for the } \\
\text { opposition, without consultations [emphasis added] and without any details outlined in its text, is because }\end{array}$ \\
\hline Conservative Party $]^{70}$ & Mr. McGuinty [Premier of the Government of Ontario]...failure to address Ontario's economic crisis." \\
\hline Robert Bailey & "Mr. McGuinty's Green Energy Act is taking away the currently legislative review process that allows \\
\hline $\begin{array}{l}{[\text { Progressive }} \\
\text { Conservative Party }]^{71}\end{array}$ & $\begin{array}{l}\text { input from individuals and local government regarding new energy projects [emphasis added]. } \\
\text { What will be next? This is a major step backward in our democratic rights." }\end{array}$ \\
\hline John O'Toole & "We support green energy and conservation...Here's why I'm having difficulty with supporting it overtly: \\
\hline & $\mathrm{h}$ public hearings around the province. I want to make \\
\hline Conservative Party $]^{72}$ & $\begin{array}{l}\text { don't like certain provisions: the warrantless entry, the overriding of municipal law and the overriding of } \\
\text { the conservation act. There are parts of this bill that the people of Ontario need to know about." }\end{array}$ \\
\hline $\begin{array}{l}\text { Phil McNeely } \\
\quad{ }_{\text {Liberal Party }]^{73}}\end{array}$ & $\begin{array}{l}\text { "There just have to be more discussions with the First Nations [emphasis added]. They have to be part of } \\
\text { this. Aboriginal partnerships and capacity-building will be important to the development of new, } \\
\text { renewable energy projects." }\end{array}$ \\
\hline $\begin{array}{l}\text { Elizabeth Witmer } \\
\quad[\text { Progressive } \\
\quad \text { Conservative Party }]^{74}\end{array}$ & $\begin{array}{l}\text { "Although I support green energy, I am concerned not only about the lack of detail in this bill, but also the } \\
\text { details that may be buried in this bill and the haste to pass this bill by the government, without } \\
\text { extensive consultation with stakeholders and the public [emphasis added]." }\end{array}$ \\
\hline $\begin{array}{l}\text { Hon. Brad Duguid } \\
\text { (Minister of } \\
\text { Aboriginal Affairs) } \\
{[\text { Liberal Party }]^{75}}\end{array}$ & $\begin{array}{l}\text { "The connection many aboriginal people feel to the land and surrounding natural resources. That } \\
\text { connection, frankly, is a reflection of the uniqueness of First Nation and Metis culture, and it's } \\
\text { something this government makes every effort to respect. Striking that balance between environmental } \\
\text { sustainability and economic growth is something we need to work on with our aboriginal partners } \\
\text { through consultation and dialogue. We do have an obligation, constitutionally, to consult [with } \\
\text { Aboriginal peoples], but we have to go beyond that [emphasis added]." }\end{array}$ \\
\hline $\begin{array}{l}\text { Sylvia Jones } \\
\quad \text { [Progressive }^{\text {Conservative Party }]^{76}}\end{array}$ & $\begin{array}{l}\text { "A constituent in my riding...has been denied the opportunity to speak before the standing committee for } \\
\text { Bill 150, the Green Energy Act.... Barbara Ashbee...is today living with the side effects of having wind } \\
\text { turbines surround her home.... Yet my constituent has been refused an opportunity to share her } \\
\text { experiences during public hearings on Bill } 150 \ldots \text {...the Green Energy Act. This act removes all over-sight } \\
\text { from municipalities. Now this government is not even going to listen to the concerns of someone who } \\
\text { has first-hand experience. It's important to the legislative process that people...be allowed to speak and } \\
\text { share their experiences...members of the Progressive Conservative Party have been calling for public } \\
\text { input...It looks as though the government is once again leaving out the most important interest group } \\
\text { when proposing new legislation: the people [emphasis added].". }\end{array}$ \\
\hline \multicolumn{2}{|c|}{ GEA Standing Committee Hearings } \\
\hline $\begin{array}{l}\text { Mr. John Yakabuski } \\
\quad \text { [Progressive }^{\text {Conservative Party }]^{77}}\end{array}$ & "Normally there's a consultative process before bills are written." \\
\hline $\begin{array}{l}\text { Beatrice Olivastri } \\
\text { (CEO Friends } \\
\text { of the Earth Canada })^{78}\end{array}$ & $\begin{array}{l}\text { "The main ministry dealing with this act, the Ministry of Energy and Infrastructure, which will be } \\
\text { responsible for the bulk of the Green Energy Act, is not currently a prescribed ministry under the } \\
\text { Environmental Bill of Rights [emphasis added], which we hold to be a very important part of our } \\
\text { democracy here in Ontario. This means that part II of the Environmental Bill of Rights, which sets } \\
\text { out a minimum level of public participation that should be met before government makes } \\
\text { decisions on certain kinds of environmentally significant projects and proposals, doesn't apply at } \\
\text { all to the Green Energy Act [emphasis added] aspect. Formal public comment periods that would } \\
\text { typically be required under EBR will not apply, and there will be no requirement to post notices on the } \\
\text { environmental registry. It's curious and inconsistent, we believe, that this ministry is still missing in } \\
\text { action under the EBR, and so we are strongly urging you to rectify that situation.", }\end{array}$ \\
\hline
\end{tabular}

\footnotetext{
${ }^{69}$ Ontario. Legislative Assembly of Ontario (Hansard). 25 February 2009 (Mr. Ted Arnott, Member of Provincial Parliament representing the Progressive Conservative Party). First Session, 39th Parliament, No. 114, 5047.

${ }^{70}$ Ontario. Legislative Assembly of Ontario (Hansard). 26 February 2009 (Mr. Peter Shurman, Member of Provincial Parliament representing the Progressive Conservative Party). First Session, 39th Parliament, No. 115, 5065.

${ }^{71}$ Ontario. Legislative Assembly of Ontario (Hansard). 26 May 2009 (Mr. Robert Bailey, Member of Provincial Parliament representing the Progressive Conservative Party). First Session, 39th Parliament, No. 115, 5086.

${ }^{72}$ Ontario. Legislative Assembly of Ontario (Hansard). 3 March 2009 (Mr. John O’Toole, Member of Provincial Parliament representing the Progressive Conservative Party). First Session, 39th Parliament, No. 117, 5174.

${ }^{73}$ Ontario. Legislative Assembly of Ontario (Hansard). 3 March 2009 (Mr. Phil McNeely, Member of Provincial Parliament representing the Liberal Party). First Session, 39th Parliament, No. 117, 5176.
}

${ }^{74}$ Ontario. Legislative Assembly of Ontario (Hansard). 9 March 2009 (Mrs. Elizabeth Witmer, Member of Provincial Parliament representing the Progressive Conservative Party). First Session, 39th Parliament, No. 120, 5330.

${ }^{75}$ Ontario. Legislative Assembly of Ontario. (Hansard). 6 April 2009 (Hon. Brad Duguid, Minister of Aboriginal Affairs). First Session, 39th Parliament, No. 132, 5883-5584.

${ }^{76}$ Ontario. Legislative Assembly of Ontario (Hansard). 8 April 2009 (Ms. Sylvia Jones, Member of Provincial Parliament representing the Progressive Conservative Party). First Session, 39th Parliament, No. 134, 5998.

${ }^{77}$ Ontario. Standing Committee on General Government (Hansard). 6 April 2009 (Mr. John Yakabuski, Member of Provincial Parliament representing the Progressive Conservative Party). First Session, 39th Parliament, G20, 397.

${ }^{78}$ Ontario. Standing Committee on General Government (Hansard). 16 April 2009 (Ms. Beatrice Olivastri, CEO of Friends of Earth). First Session, 39th Parliament, G24, 578. 
Table 3. An Indigenous Perspective of the Government of Ontario's Consultative Process from Bill 173 (Mining Act Amendment) and Bill 191 (Far North Act) Joint Standing Committee Hearings in 2009

Speaker/citation

Grand Chief Stan Beardy of the Nishnawbe Aski Nation $^{79}$

Grand Chief Stan Louttit of the Mushkegowuk Council $^{80}$

Sam McKay of the Kitchenuhmaykoosib Inninuwug ${ }^{81}$

Chief Keeter Corston of the Chapleau Cree First Nation in the Nishnawbe Aski Nation $^{82}$

Chief David Babin of the Wahgoshig First Nation in the Nishnawbe Aski Nation $^{83}$

Gregory Koostachin Elder of the Mushkegowuk First Nation in the Nishnawbe Aski Nation $^{84}$
Comments

"I hear a lot about consultation these days, and about Ontario's legal duties to consult. I want to be clear about this: Just because I have appeared here today does not mean you have consulted with the First Nations in Nishnawbe Aski Nation [NAN, 49 First Nations located in northern Ontario]. NAN, the organization I represent, a political organization, does not have any aboriginal and treaty rights [emphasis added]. This hearing is not consultation...each First Nations should be consulted without artificial timelines...It's the rights-holders, the people on the land, the First Nations level, the leadership at the community level who hold those aboriginal and treaty rights [emphasis added], and they are the ones who need to be consulted. NAN's role, basically, is to facilitate that process to ensure that they are being heard, that the people who need to talk to them do consult with them... If there's a legal requirement of the crown's responsibility to consult with them, we would expect that an attempt be made to talk to those people in their own language so that they understand what is being proposed to them.

The north is our homeland and we govern and protect it through our inherent right, given to us by the Creator. Since time immemorial, our people have exercised our inherent right and protected the lands. That is why they are still in pristine condition. And we will continue to protect our lands for future generations...the far north, it's only First Nations people who live there. We have lived there for close to 10,000 years and we have preserved the natural environment up until now. We will continue to protect the natural environment."

"We have been involved right from the outset - not in our terms of what we desired to be consultation [emphasis added]. Ontario has attempted to have discussions by bringing people together in urban centres and thereby calling it consultation...We've told the province from day one that it is the people in our home communities who need to have the discussion [emphasis added] and need to have input into the process. That has fallen on deaf ears."

"Our concepts of preserving Mother Nature...We are one with the land, we depend on it to feed our families, and we have thousands of years of intergenerational experience with how to live in harmony with the land and preserve it, not destroy it in a few years [through resource development]."

"When we're talking about the land, the people are connected to the land. First Nations people are stewards of the land; it's part of us...you [Government of Ontario] polluted everything; you [Government of Ontario] polluted all south of 50 [parallel]...and still you want more [emphasis added]. You want to go north of 50 now; you want to go north there because you've ruined it here. I've warned the northern chiefs [emphasis added]. I live south of the 50th parallel, and I've seen the behaviour. The behaviour hasn't changed one bit. These people are here to protect their homelands that belong to them. It doesn't belong to Ontario."

"In the far north, we're just starting to face that. I'm in the Timmins [northern Ontario, Canada] area, where development is very, very high...they leave a lot of pollutants behind. We worry about our water [emphasis added]. We have some of the cleanest water in Canada, and we still have to worry about it because of the development that's happening around us. Yet you [Government of Ontario] give these permits out to them like it was nothing [emphasis added]...We've got to think about tomorrow. We've got to think about our kids, our children who are coming. What are we going to leave them? Are they going to live on nothing?

I was talking about development with the hydro dams and the damage they've done. They washed away our graveyards into the lakes, and yet development still happens [emphasis added]...Development, yes, but...We have to come to some sort of conclusion on how we're going to develop our territories...We can't even go hunting; we can't even go fishing...You [Government of Ontario] took us off our land. You took us away from our home so you can develop industry...The point is what? Destroying the lands, our rivers, our waters? What kind of water are we drinking today? It all has to be treated...I don't think First Nations have ever destroyed any lands. I can't think of any."

"I am one of the elders amongst many others as I represent the east Mushkegowuk territory...I just wanted to say that the elders here, the Nishnawbe Aski, some of them are there behind me, and the many other elders - our job is to give advice to our chiefs, to remember not to give their land anymore to anyone, to try to keep their land, what is left out there, for us people.

The [Ontario] provincial government is issuing permits without any consultation with us. And this is why we give advice to our chiefs that enough is enough. We will hold what is left out there and then we will fight for it...our land is not for sale. It is not for sale. We want to keep that [emphasis added]."

\footnotetext{
${ }^{79}$ Ontario. Standing Committee on General Government (Hansard). 6 August 2009 (Grand Chief Stan Beardy of the Nishawbe Aski Nation). First Session, 39th Parliament, G32, 828-831.

${ }^{80}$ Ontario. Standing Committee on General Government (Hansard). 13 August 2009 (Grand Chief Stan Louttit of the Muchkegowuk Council). First Session, 39th Parliament, G36, 985 .

${ }^{81}$ Ontario. Standing Committee on General Government (Hansard). 11 August 2009 (Mr. Sam McKay). First Session, 39th Parliament, G34, 912.
}

\footnotetext{
${ }^{82}$ Ontario. Standing Committee on General Government (Hansard). 12 August 2009 (Chief Keeter Corston of the Chapleau Cree First Nation in the Nishnawbe Aski Nation). First Session, 39th Parliament, G35, 955-956.

${ }^{83}$ Ontario. Standing Committee on General Government (Hansard). 12 August 2009 (Chief David Babin of the Wahgoshig First Nation in the Nishnawbe Aski Nation). First Session, 39th Parliament, G35, 955.

${ }^{84}$ Ontario. Standing Committee on General Government (Hansard). 12 August 2009 (Mr. Gregory Koostachin Elder of the Mushkegowuk First Nation in the Nishnawbe Aski Nation). First Session, 39th Parliament, G35, 958.
} 
Table 4. Nonelected First Nation "Representation" Who Presented at the Green Energy Act Standing Committee Hearings

\begin{tabular}{ll}
\hline Speaker/citation & \multicolumn{1}{c}{ Position/relevance } \\
\hline $\begin{array}{l}\text { Percy Bresnahan } \\
\text { Deborah Doncaster }\end{array}$ & $\begin{array}{l}\text { Mayor of the Township of South Algonquin } \\
\text { Executive Director of the Community Power Fund and Chair of the Green Energy Act } \\
\text { Alliance }\end{array}$ \\
$\begin{array}{l}\text { Ed Chilton } \\
\text { Broject Coordinator for Five Nations Energy Inc., }\end{array}$ \\
Dee Whirector of Economic Development for the Pic River First Nation, Presenting on the \\
Behalf of the First Nations Energy Alliance
\end{tabular}

article. I would like to encourage those who reads this to expand and discuss these topics at more length in further research.

\section{CONCLUSION}

Consequently, determining the points of improvement is a simple matter given how the problematic points have been outlined. The act failed to incorporate meaningful critique during its stages as a bill — the act did not provide a sufficient definition of the central term of green energyand there was a failure in executing the fiduciary duty. Given these shortcomings, it is suggested that relevant terms must be clearly defined in bills; and relevant parties should be involved in the discussion in meaningful ways to prevent instances of a haphazard consultation process. All of these suggestions should occur at the earliest point possible for the bill and should be ongoing to encourage sustainability and dynamic evolution of policies and laws in meaningful ways.

\footnotetext{
${ }^{85}$ Ontario. Standing Committee on General Government (Hansard). 6 April 2009 (Mr. Percy Bresnahan, Mayor of the South Algonquin Township). First Session, 39th Parliament, G20, 400.

${ }^{86}$ Ontario. Standing Committee on General Government (Hansard). 8 April 2009 (Ms. Deborah Doncaster, Executive Director of the Community Power Fund and Chair of the Green Energy Act Alliance). First Session, 39th Parliament, G21, 416.

${ }^{87}$ Ontario. Standing Committee on General Government (Hansard). 14 April 2009 (Mr. Ed Chilton, Project Coordinator for Five Nations Energy Inc.). First Session, 39th Parliament, $\mathrm{G} 22,457$.

${ }^{88}$ Ontario. Standing Committee on General Government (Hansard). 14 April 2009 (Mr. Byron LeClair, Director of Economic Development for the Pic River First Nation). First Session, 39th Parliament, G22, 463.

${ }^{89}$ Ontario. Standing Committee on General Government (Hansard). 15 April 2009 (Mr. Lee White, Director of Economic Development on the Walpole Island First Nation, Board Member of the First Nations Energy Alliance). First Session, 39th Parliament, G23, 522.
}

\section{ACKNOWLEDGMENTS}

I thank the Social Sciences and Humanities Research Council of Canada for funding support, and anonymous reviewers for comments that improved the article.

\section{AUTHOR DISCLOSURE STATEMENT}

No competing financial interests exist.

\section{FUNDING INFORMATION}

Social Sciences and Humanities Research Council. Funding number: 435-2016-135.

Address correspondence to: Stephen R.J. Tsuji School of Environment, Resources, and Sustainability University of Waterloo 200 University Avenue West Waterloo Ontario N2L $3 G 1$ Canada

E-mail: srjtsuji@uwaterloo.ca

\footnotetext{
${ }^{90}$ Ontario. Standing Committee on General Government (Hansard). 15 April 2009 (Mr. William Big Bull, representing Big Bull's Energy Consulting). First Session, 39th Parliament, G23, 533.

${ }^{91}$ Ontario. Standing Committee on General Government (Hansard). 16 April 2009 (Mr. Kristopher Stevens, Executive Director of the Ontario Sustainable Energy Association). First Session, 39th Parliament, G24, 580.

${ }^{92}$ Ontario. Standing Committee on General Government (Hansard). 16 April 2009 (Mr. Tim Weis, Engineer and Director of Renewable Energy and Energy Efficiency at the Pembina Institute). First Session, 39th Parliament, G24, 600-601.

${ }^{93}$ Ontario. Standing Committee on General Government (Hansard). 20 April 2009 (Ms. Cherie Brant, Counsel to the First Nations Energy Alliance). First Session, 39th Parliament, G25, 617.

${ }^{94}$ Ontario. Standing Committee on General Government (Hansard). 20 April 2009 (Mr. Brent Kopperson, Executive Director of the Windfall Ecology Center, representing Chippewas of Georgina Island First Nation). First Session, 39th Parliament, G25, 638.
} 